\title{
THE LONG HISTORY OF LUTHERANISM IN SCANDINAVIA. FROM STATE RELIGION TO THE PEOPLE'S CHURCH
}

\author{
PIRJO MARKKOLA*
}

University of Jyväskylä / University of Tampere

\begin{abstract}
As the main religion of Finland, but also of entire Scandinavia, Lutheranism has a centuries-long history. Until 1809 Finland formed the eastern part of the Swedish Kingdom, from 1809 to 1917 it was a Grand Duchy within the Russian Empire, and in 1917 Finland gained independence. In the 1520s the Lutheran Reformation reached the Swedish realm and gradually Lutheranism was made the state religion in Sweden. In the 19th century the Emperor in Russia recognized the official Lutheran confession and the status of the Lutheran Church as a state church in Finland. In the 20th century Lutheran church leaders preferred to use the concept people's church. The Lutheran Church is still the majority church. In the beginning of 2015, some 74 percent of all Finns were members of the Evangelical Lutheran Church of Finland. In this issue of Perichoresis, Finnish historians interested in the role of church and Christian faith in society look at the religious history of Finland and Scandinavia. The articles are mainly organized in chronological order, starting from the early modern period and covering several centuries until the late 20th century and the building of the welfare state in Finland. This introductory article gives a brief overview of state-church relations in Finland and presents the overall theme of this issue focusing on Finnish Lutheranism. Our studies suggest that 16th and early 17th century Finland may not have been quite so devoutly Lutheran as is commonly claimed, and that late 20th century Finland may have been more Lutheran than is commonly realized.
\end{abstract}

KEY WORDS: Lutheranism, Nordic countries, religion, state-church relations, history

\section{Introduction}

Finland is a Lutheran country. At the beginning of 2015 the vast majority of the Finnish population, i. e. 74 percent of all Finns, were members of the Evangelical Lutheran Church of Finland (www.evl.fi). The Finnish understanding of work ethics is often explained by reference to Lutheran theology, and many cultural features in Finland are described as deriving from the Lutheran past and present. At the same time, however, Finland today is perceived to be a secular country where religion is a private issue. Churches stand empty on Sunday mornings and only some special services, such as those at Christmas and Easter, manage to attract more people. Nevertheless, to talk about the death of Christian values, as 
Callum G. Brown describes the British development (Brown 2001: 1-2), is hardly justified in the Finnish context.

Until 1809 Finland constituted the eastern part of the Swedish Kingdom, from 1809 to 1917 Finland ranked as a Grand Duchy within the Russian Empire, and in 1917 Finland gained independence and soon became a republic. Lutheranism as the main religion has a centuries-long history in Finland. Both scholarly works and textbooks used in Finnish schools explain that the Lutheran Reformation reached the Northern corners of Europe in the 1520s. In 2017 the long history of Lutheranism will be celebrated in Finland, too, commemorating the German reformer Martin Luther's 95 theses presented in Wittenberg in 1517, and all the theological and ecclesiastical consequences contingent upon them. When it comes to the 20th century, the same textbooks usually conclude that Finland became highly secularized and religion changed to be a private issue. These common notions, however, deserve to be further specified and, indeed, some of them need to be called into question. In this issue of Perichoresis, Finnish historians interested in the role of church and Christian faith in society look at various aspects of the religious history of Finland. The articles cover a long time period from the postReformation era to the post World War II era in Finland. Our studies suggest that 16th and early 17th century Finland may not have been quite so devoutly Lutheran as is commonly claimed, and that late 20th century Finland may have been more Lutheran than is commonly realized.

Why is the religious history of Finland so interesting as to merit discussion in English in an issue of a theological journal? According to our understanding there are several reasons to focus on one small country. First, as one of the Nordic countries Finland belongs to the Lutheran stronghold of Europe. Church historians usually distinguish the Scandinavian countries for their long tradition of Evangelical Lutheran State Churches. The Reformation in the early 16th century is often understood as a decisive period for the strong ties between Church and state, but historians and church historians emphasize that the connections in fact date back to the Middle Ages, when the Crown followed the Church to the new parts of the realm (Lavery 2006: 32-33). Nevertheless, after the Reformation the Church was gradually integrated into the governing of the state, the Church was more or less transformed according to Lutheran doctrine and Lutheranism gradually achieved a hegemonic status in the Kingdom. After 1809, in the Grand Duchy of Finland, the social structure and legal system remained Scandinavian, as the Emperor in Russia recognized the Swedish legislation and earlier administrative institutions for Finland, including official Lutheran confession and the status of the Lutheran Church as a state church. After 1917 the strong position of the Lutheran church continued in independent Finland (Lavery 2006: passim.; Kirby 2006: passim.; Heininen \& Heikkilä 1996: 162-163). Therefore, our focus on one country provides concrete and contextualized examples of the state-church relation in the Protestant world. 
Second, many books on the history of Europe tend to focus on Germany, France, Britain, and other prominent countries and regions, paying little attention to the margins of Europe (e. g. Rietbergen 2015). Finland, as a small country in Northern Europe, is an example of those regions where the Christian church has for centuries contributed to certain European values and experiences shared by many other small countries. Due to a shared experience both in terms of political history and of religion in particular, Finland has much in common with its Nordic neighbours Sweden, Denmark, Norway, and Iceland. Until the beginning of the 20th century, virtually the whole populations of the Nordic countries were Lutheran and the strong position of the Lutheran churches continued in Finland as also in its neighbouring countries (Thorkildsen 1997: 138; Stenius 1997: 161-171; Markkola 2000: 12). By looking at what may be called 'the long history' of institutionalized Lutheranism we can gain a more profound understanding of the role of the majority church among the population.

Third, the societal roles of the majority churches are historically constructed and based on their theological and confessional traditions. In international comparisons Catholicism, Lutheranism and Reformed Protestant traditions are discussed as three regimes with differing policy outcomes, and specific features are attributed to the Lutheran churches. The German social scientist Sigrun Kahl, in particular, argues that religion plays a key role in the ways in which social policies and poverty policies have been historically constructed and understood. She states that in spite of the fact that denominational social doctrines can be difficult to trace they 'have for centuries shaped both perspectives on poverty and the institutions of poor relief, even when they became part of state poverty policy' (Kahl 2005: 122). Kahl points out how European welfare regimes reflect differences between Catholic, Reformed and Lutheran social doctrines (Kahl 2005; Kahl 2009). Similar differences have been suggested by other scholars, too. According to recent comparative studies on religion and welfare in Europe, countries with the Roman Catholic Church as the majority church tend to be family-centred in their welfare policies, whereas countries with Reformed majority churches are more market-oriented and countries with Lutheran majority churches assign a greater role to the public sector (Bäckström et al. 2010, 2011). Bäckström and his colleagues, however, mainly work on contemporary material, comparing current welfare regimes and current churches. We therefore feel justified in providing contextualized histories, or historicized contexts, from one Protestant region in Europe with the Lutheran Church as the majority church.

\section{From State Religion to People's Church}

The five Nordic countries share an interconnected political and religious history. At the end of the Middle Ages the whole area was united under the Crown of Denmark by King Olav's mother Margrethe (1353-1412), who until her death also acted as the real ruler of the Kingdom. By the end of the fifteenth century the 
union was dissolved and the area divided. In 1523 Gustav Vasa was elected King of Sweden. For the history of Lutheranism in the Swedish realm, Gustav Vasa was to play a crucial role. He was inspired by Lutheran teaching on state-church relations and, in particular, by the opportunities he perceived in the new thought to gain access to Church property. In 1527 he confiscated what he defined as the surplus property of the Church and declared that the pure word of God should be preached in Sweden (Lavery 2006: 38-39; Heininen \& Heikkilä 1996: 61-63). The King was not, however, greatly interested in theological matters and three of his sons who succeeded him on the throne were divided in their theological and religious preferences. The competition between the Catholic and Protestant faith, symbols and rituals continued throughout the 16th century. In 1540 Gustav Vasa was made the supreme head of the Church in the Swedish Kingdom. The Lutheran confession was more formally established at the Uppsala Synod in 1593, and the grip of Lutheran bishops and pastors on theological issues tightened, but the victory of Lutheranism in Sweden and its eastern part, in particular, was not a sudden process. Both popular beliefs and the Catholic faith lived on alongside new Lutheran ideas in the 17th century (see the articles of Hiljanen and Kuha in this issue; Lavery 2006: 39-41).

Church historians often emphasize the division in the Scandinavian countries, where Sweden and Finland belong to one group sharing many similar features, and Denmark, Norway and Iceland, for their part, have in common their social patterns and state-church relations. Some differences can be traced to the era of the Reformation, because the Reformation was more directly controlled by the state in the territory of Denmark, Norway, and Iceland, whereas the Church in Sweden and Finland retained more independence (Thorkildsen 1997: 139-140). In the 19th and 20th centuries the Lutheran Church of Finland built up its institutions on the Swedish heritage. Nonetheless, despite some degree of independence of the Church the ties between the state and the church were close.

As the Finnish church historian Juha Seppo has argued, Lutheran confession in early modern Sweden was not only a religious matter. It was also political. According to Seppo, close state-church relations defined the state itself as religious confession and church order had political importance (Seppo 1994: 37). On the one hand the religious uniformity of the people was the social basis of the early modern state, on the other hand 'confession demarcated the territory of a state and people from other states', as Dag Thorkildsen has characterized the nature of the confessional state (Thorkildsen 1997: 138). To be a Swedish subject in postReformation Sweden was to be Lutheran. Only Lutherans were allowed to hold public office, only Lutherans were allowed to be represented in the Diet of Four Estates and the normative level, codified in the Church Law of 1686, suggested that only Lutherans were allowed to reside in Sweden and practise religion (Lavery 2006: 39-40). In the early modern period, however, some exceptions were condoned and non-Lutherans were tolerated to some extent. Non-Lutheran mer- 
chants and other visitors, for example, were allowed to practise their respective religions in private. The tradition of the Lutheran confession of the state, however, continued throughout the 19th century and the early 20th century until Finland gained independence in the late 1910s. As far as the Constitution was concerned, the Finnish state was a confessional Lutheran state until the new Constitution of 1919. The constitution signified an important change in state-church relations by separating confession and state administration; however, the established status of the Lutheran Church was upheld in the Constitution (Pirinen 1968: 77; Lavery 2006: 95).

For several historical reasons the influence of Lutheranism in Finland and the other Nordic countries is a wider cultural and spiritual phenomenon than the direct operations of the Church. The governing of the Church was integrated into the governing of the state, and the clergy represented the state as well as the Church (Seppo 1994: 36-38; Thorkildsen 1997: 138-141; Knudsen 2000: 20-61). The role of the Lutheran Church and the Lutheran clergy was particularly crucial in local administration. Local administration was organized by the parishes which, in fact, formed the tightest administrative network in rural society. Furthermore, judged by European standards the Swedish degree of self-government by the parishes is considered exceptional (Soikkanen 1966: 92-93; Pulma 1985: 80-86; Pulma 1994: 32-33). Yet the state began at an early stage to dictate how poor relief and other administrative efforts should be organized by parishes. The Swedish Church Law of 1686 defined state-church relations and stipulated both centralized and local responsibilities (Church Law 1686). In 1723, the privileges and duties of the estate of clergy were further defined. Local administration, including parish meetings, where decisions on public duties, poor relief and elementary education were taken among others, became the responsibility of the pastors. Moreover, in the course of the 18th century more and more administrative duties were delegated to the pastors. Many forms of educational and social services were explicitly based on local arrangements. For example, the legislation of 1763 concerning poor relief, hospitals and orphanages demanded that the parishes should finance their poor relief by local taxation. Providing the rudiments of learning to all parishioners was also made the duty of the local clergy. A certain division of labour between the state and the local authorities developed at a relatively early stage. The care of the incurably sick, the control of the able-bodied poor and the punishment of vagrants were traditionally regarded as matters of the state, whereas poor relief, the care of orphans and neglected children and moral education were considered to be the province of the parishes and to some extent of individual charity, too. It has to be emphasized, however, that the primary responsibility invariably rested with the family, and the parish would only help if needy individuals had no family or household to take care of them (Pulma 1985: 80-89; Satka 1995: 20-21). 
In the early 18th century, after the Great Northern War, Sweden lost its status as the great power of Northern Europe. Therefore concerns about a decline in the population and a shortage of workforce were expressed, resulting in strict regulation of the population and an increasing interest in statistics as a means of control. This development also increased the administrative burden of the local clergy. The 18th century can be characterized as an age of population policy which continued to put its stamp on the next century as well. The landless population was subjected to the landowners; furthermore, vagrancy and begging were explicitly forbidden and punished. The fear of a possible lack of workforce made it necessary to introduce new restrictions such as restrictions on migration and compulsory service for the landless population. For example, it was forbidden to move from one parish or village to another without a written document from the clergy (Pulma 1994: 47).

In the 19th century the close relationship between Church and state was challenged in many ways. As Sweden lost its eastern part (modern Finland) to Russia, the inhabitants of the new Grand Duchy of Finland found themselves in an ecclesiastically paradoxical situation. The Russian Orthodox Emperor ruled the Grand Duchy, in which administration and central institutions were based on the Swedish heritage and the Lutheran confession. Since the 16th century the Swedish King had been the head of the Lutheran Church. Now the Russian Emperor assumed the same role in spite of the fact that he was not Lutheran. Moreover, the status of the Russian Orthodox minority in the Grand Duchy needed to be resolved, and the Orthodox population was granted the same civil rights as Lutherans (Heininen \& Heikkilä 1996; Lavery 2006).

The 1860s witnessed two decisive turning points in state-church relations. First, local administration was re-organized when new secular municipalities were established and many administrative duties formerly assigned to the parishes were transferred to these municipalities. Poor relief, popular education and local administration were no longer the responsibility of parishes and pastors (Soikkanen 1966). Another turning point was the new Ecclesiastical Act passed in the late 1860s. This was the first piece of legislation to explicitly designate the Church as an institution composed of its members, thus in a symbolic way separating the Church from the state and also leaning slightly towards the freedom of religion. As a sign of the autonomous position of the Church the General Synod was established. Only the General Synod had the right to propose changes in the Ecclesiastical Act and decide on the Ecclesiastical Order (Heininen \& Heikkilä 1996: 185). The Ecclesiastical Act, however, was passed by the Diet of Four Estates, and later on, after the parliamentary reform of 1906, Parliament continued to pass legislation concerning the Church. Nevertheless, the Church leaders chose to define the Lutheran Church as a people's church rather than as the state church. This definition as a people's church maintains that it is the Church of the majority of the population, not the church of the state. 
In terms of religious freedom, Finland was relatively restrictive until the 1920s. The status of the Orthodox Church was equated with that of the Lutheran Church, and both churches are today considered people's churches. Otherwise the long conformity with institutional Lutheranism was relatively well established until the 1860s, when a new Ecclesiastical Act was passed. In the 1860s and 1870s an increasing number of new Protestant revivalist movements, such as Baptism and Methodism, reached Finland. The first Dissenters' Act was not passed until 1889. It made the foundation of non-Lutheran Protestant denominations permissible and allowed Lutherans to leave their church in order to join another Protestant denomination. Roman Catholics and non-Christians were not allowed, nor was it possible to leave the Orthodox Church (Heininen \& Heikkilä 1996: 206207; Lavery 2006: 65-66). Both Baptists and Methodists exercised their legal right to organize their adherents and churches, whereas supporters of some other movements, such as the Free Mission, formally remained members of the Lutheran Church until the 1920s. The Constitution of 1919 guaranteed religious freedom, which was more precisely defined in the Freedom of Religion Act of 1922. The introduction of freedom of religion finally allowed non-Christian denominations to be formally organized in Finland. In addition to a variety of Christian denominations, small Muslim and Jewish communities were formally established in the 1920s. The Freedom of Religion Act also allowed non-religious choices. The Lutheran Church leaders were concerned about the effects of the new legislation, and it was feared that supporters of the labour movement, in particular, would leave the majority church, but the fear turned out to be exaggerated. In 1923 some 22500 Finns left the Lutheran Church and about 21500 of them did not join any other religious denominations. With a population of a little over three million people these figures did not mean particularly dramatic losses to the majority church (Seppo 1983; Statistical Yearbook of Finland 1930).

Another aspect of the impact of Lutheranism is the way in which the majority of Finns have chosen to remain members of their Church. In the 1950s, for example, some 93-95 percent of the population belonged to the Lutheran Church; in the 1970s, the figure was still over 90 percent, and a more dramatic decline in membership figures did not take place until the 21 st century. In this respect too, Finland shares a similar pattern with its Nordic neighbours. Lutheranism continues to be the denomination of the Nordic majority: the relatively recent membership figures range from 67.5 percent in Sweden to 79 percent in Denmark. Norway is close to the Danish level, with 77 percent. Moreover, even in Sweden, where the membership figures are the lowest, the percentage did not fall below 80 
until as late as in 2003. ${ }^{1}$ Finland with its current membership figures is really close to its neighbours.

In daily life, the Lutheran Church has been prominent in various ceremonies and transitions of its members' family events. In post-World War II Finland, religious rites of passage were highly appreciated and confirmation at the age of 15 , for example, remained a relatively unquestioned life event. The post-war period brought about some changes, but as late as in 2007, 84 percent of Finnish of children were baptized and over 90 percent of funerals took place in a Lutheran context. The figures on marriage were the lowest, with some 60 percent of marriages in Finland solemnized in the church or in front of the clergy. Belonging to the Church was not only a religious choice or a moral statement: membership involved-and continues to involve-paying Church taxes, which, since 1960, have been collected by the state along with income tax (Markkola 2011: 106).

Thus despite the freedom of religion, the Lutheran Church and the Orthodox Church maintained a special position in relation to the state when compared to other denominations. Among the religious communities in Finland only the Lutheran Church and the Orthodox Church enjoy the right to taxation; furthermore, the Church taxation is integrated into the general taxation (Markkola 2011: 106). As regards the state, religious communities in Finland are not equal, because the people's churches enjoy a privileged position.

\section{The Contents of this Issue}

In this issue historians from three Finnish universities discuss their ongoing or recently completed research projects on various aspects of religion in Finland with references to the whole of Scandinavia. We have deliberately chosen to apply a long perspective, covering church histories from the 16th to the 20th centuries. We do not represent one single approach or school of thought in historical research. While some of us represent institutional approaches and discuss the institutions of church and state from various perspectives, others seek inspiration from anthropological approaches to religion or apply sociological concepts such as 'lived religion' to conceptualize the agency of religious individuals.

This issue is mainly organized in chronological order, starting from the early modern period and covering several centuries until the late 20th century and the building of the welfare state in Finland. The first research article is based on doctoral candidate Miia Kuha's forthcoming dissertation on religious life in the early modern period in the eastern parts of Finland. Eastern Finland was a sparsely populated region where distances between churches were wide and parishes were 
geographically large. The control of the Crown and the Church over the population was still in the making.

In this context, Miia Kuha discusses the problems faced by clerical and secular authorities in their attempts to enforce church attendance in post-Reformation Finland. She opens up new perspectives on the Lutheran Church, which tried to establish appropriate piety and decent Christian behaviour in the remote rural parishes located on the margins of Christian Europe. Religious conformity, in particular, was considered vital for the success of the state after the Lutheran confession had been established, and for that purpose all parishioners were expected to attend Sunday services regularly. Kuha maintains that absences from church services were punishable by law, and the local courts seriously attempted to assist the Church to uphold its authority. She further argues that the 17 th century witnessed a significant tightening of the legislation relating not only to church attendance but also to other breaches of the Sabbath, and severe punishments were introduced. The tightening legislation and severe punishments are by no means news to historians or church historians; however, much more interesting are the ways in which parishioners themselves made tremendous efforts to attend church in the way they found necessary. Miia Kuha succeeds in accessing the parishioners' perspective on religious and spiritual life in early modern rural society. On the Christian periphery of Europe, according to Kuha, a clear understanding of sacred time and important holy days was established. In remote villages and sparsely populated parishes, attending church could mean be a demanding effort. Yet long distances and trying conditions did not hinder people from coming to church on a great holy day. On other Sundays parishioners considered church attendance less important and then suddenly long distances and trying conditions became their most important rhetorical excuses for staying at home.

The Lutheran Reformation in the Nordic countries is often discussed from the point of view of bishops and church leaders. The ways in which the Swedish Crown confiscated church property, imposed new taxes and limited the rights of Bishops are usually cited as examples of the impact of the Reformation. From that perspective, it is legitimate to argue that the Reformation caused the power of the King to grow. However, the power of the state can also be examined from the perspective of parishes. In this issue, doctoral candidate Mikko Hiljanen approaches state-church relations and the impact of the Reformation in Sweden by looking at clerical appointment processes during some post-Reformation decades, namely the period 1560-1611. His aim is to ascertain whether the King of Sweden could appoint pastors independently, and if not, with whom he was compelled to share the power. His article suggests that the role of the Crown in clerical appointment processes varied. Of course, some parishes and some livings were more important than others to the King, but the variation indicates that the state's power over the Church was more limited than earlier research has suggested. 
Clerical appointment processes are further discussed by Antti Räihä, who draws on material from his ongoing post-doctoral research project on the Lutheran clergy in the Russo-Swedish borderlands in the 18th century. The borderlands in Eastern Finland used to belong to the Swedish Kingdom, but in the 18th century Sweden lost them to Russia. Räihä reminds his readers that the parishioners' right to participate in and influence the choice of local clergy in Sweden and Finland can be traced back as far as late Medieval times. The historiography in church history usually describes the procedures for electing clergymen as a Nordic feature and considers them crucial in the formation of local self-government. Antti Räihä, for his part, examines clerical appointment processes in a particular context in which the rules were renegotiated and the scope for action was modified. His article represents a unique analysis of the ways in which the Swedish legislation was applied in 18th century imperial Russia. The peace treaty between Sweden and Russia of 1743 kept the Swedish legislation in force; moreover, the inhabitants were allowed to practise the Lutheran religion. For administrative purposes, the Consistory District of Fredrikshamn was formed. By scrutinizing the Lutheran parishioners' opportunities and willingness to influence the appointment of their pastors Räihä, in fact, presents the first comprehensive account of the procedures for electing pastors in the Consistory District of Fredrikshamn. Räihäs' article discusses not only the development of the local political culture but also the interaction between the central power and local society in the 18th century.

In the 19th century, new religious movements came to challenge the religious circumstances of Finland. From the 18th century onwards Pietism and other revivalist movements introduced new elements into spiritual life. The late 19 th century, in particular, witnessed the arrival of Anglo-American revivalist movements. Baptism, Methodism, the Salvation Army, and the Free Mission were newcomers that challenged the Lutheran hegemony in Finland (Markkola 2002). This development is analysed by Johanna Annola, who takes the case of one private orphanage to render comprehensible the tensions brought about by the new understandings of Christianity and spirituality. She contrasts the Evangelical Revivalist conviction of a primary school teacher, Emma Mäkinen, and the state control of poor relief at the turn of the 20th century. Mäkinen's philanthropic work among neglected children was motivated by her Evangelical Revivalist conviction. She believed in the transformative power of faith, and therefore considered it appropriate to establish an orphanage next to a shelter for 'fallen' women. This decision was strongly disapproved of not only by the State Inspector of Poor Relief, but also by the general public. They emphasized the legislative and moral aspects of social work. Annola shows how the authority of the Lutheran State Church was challenged by individual voluntary agency represented by the Evangelical Revivalist Free Mission. 
The last article in this issue about Lutheranism in Finland takes us to some current controversies in the field of flourishing Nordic welfare state research. Since the 1990s historians and social scientists have debated the impact of Lutheranism in the making of the Nordic welfare state. This debate was initiated by Danish, Finnish, and Norwegian scholars. While some of them argued that the long history of Lutheran poor relief and popular education created preconditions for extensive welfare policies in the 20th century (Knudsen 2000), others point out similarities between the principles of Lutheran doctrine and the welfare state. The principles of equality and universalism have been found in both Lutheran doctrine and Nordic welfare policies (Thorkildsen 1997). The dominance of Lutheranism has also been seen as an explanatory factor for the culture of homogeneity (Stenius 1997). Moreover, some scholars have examined the views of the Lutheran clergy and church leaders (e. g. Tønnessen 2000, 2014; Petersen \& Petersen 2014; Markkola 2014). Yet without new empirical evidence and new perspectives these debates could be continued indefinitely. The argumentation will obviously remain rather fruitless without an attempt to analyse the religious thought and theological considerations of the leading experts who designed welfare policies. In this issue, Hanna Lindberg goes behind the scenes and examines the Finnish Professor Heikki Waris, who was both a devout Christian and one of the leading experts in Finnish welfare policies in the 1950s, 1960s and 1970s. She studies the role of Christianity in the work of Heikki Waris, professor of social policy at the University of Helsinki. Lindberg draws attention to the importance of Christianity and the Lutheran Church when analysing the work of a main architect of the Finnish welfare state. She argues that Waris' background within the Settlement movement influenced his later academic and social political work. Furthermore, she shows how Waris dealt with religion, Christianity, the Lutheran Church and faith in his work on social policy and social change. Waris was not only a respected welfare state expert and researcher; he also commanded the attention and trust of the Lutheran Church in his defence of welfare policies.

\section{Bibliography}

Bäckström A, Davie G, Edgardh N, and Pettersson P (eds) (2010) Religion and Welfare in 21st Century Europe, Volume 1. Farnham: Ashgate.

Bäckström A, Davie G, Edgardh N, and Pettersson P (eds) (2011) Religion and Welfare in 21st Century Europe, Volume 2. Farnham: Ashgate.

Brown CG (2001) The Death of Christian Britain. Understanding secularization 18002000. London and New York, NY: Routledge.

Church Law of 1686 (Kircko-Laki ja Ordningi 1686, Turku 1688). Reprinted by the Finnish Literature Society, Helsinki 1986.

Evangelical Lutheran Church of Finland. www.evl.fi (accessed 10 September 2015). 
Heininen S and Heikkilä M (1996) Suomen kirkkohistoria. Helsinki: Edita.

Kahl S (2005) The religious roots of modern poverty policy: Catholic, Lutheran, and Reformed Protestant traditions compared. Archives Européennes de Sociologie 66: 91-126.

Kahl S (2009) Religious Doctrines and Poor Relief: A Different Causal Pathway. In: van Kersbergen K \& Manow T (eds) Religion, Class Coalitions, and Welfare States, Cambridge: Cambridge University Press, pp. 267-295.

Kirby D (2006) A Concise History of Finland. Cambridge: Cambridge University Press.

Knudsen T (ed) (2000) Den nordiske protestantisme og velferdsstaten. Aarhus: Aarhus University Press.

Lavery J (2006) The History of Finland. Westport, CT: Greenwood Press.

Markkola P (2000) Introduction: The Lutheran Context of Nordic Women's History. In Markkola P (ed) Gender and Vocation. Women, Religion and Social Change in the Nordic Countries, 1830-1940. Helsinki: Finnish Literature Society, pp. 926.

Markkola P (2002) Synti ja siveys. Naiset, uskonto ja sosiaalinen työ Suomessa 18601920. Helsinki: Finnish Literature Society.

Markkola P (2011) The Lutheran Nordic welfare states. In Kettunen P and Petersen K (eds) Beyond Welfare State Models. Transnational Historical Perspectives on Social Policy. Cheltenham: Edward Elgar, pp. 102-118.

Markkola P (2014) Focusing on the Family: The Lutheran Church and the Making of the Nordic Welfare State in Finland, 1940s to 1960s. Journal of Church and State 56(1): 60-80.

Markkola P and Naumann IK (2014) Lutheranism and the Nordic Welfare States in Comparison. Journal of State and Church 56(1): 1-12.

Østergård U (1997) The Geopolitics of Nordic Identity. In Sørensen $\varnothing$ and Stråth B (eds) The Cultural Construction of Norden. Oslo: Scandinavian University Press, pp. 25-71.

Petersen JH and Petersen K (2014) Autonomy, Cooperation or Colonization? Christian Philanthropy and State Welfare in Denmark. Journal of Church and State 56(1): 81-104.

Pirinen K (1968) Kirkko ja valtio. In: Nikolainen AT \& al (eds) Kirkko Suomessa. Helsinki: Weilin+Göös.

Pulma P (1985) Fattigvård $i$ frihetstidens Finland. En undersökning om förhållandet mellan centralmakt och lokalsamhälle. Helsinki: Societas Historica Finlandiae.

Pulma P (1994) Vaivaisten valtakunta. In: Jaakkola J, Pulma P, Satka M, and Urponen K (eds) Armeliaisuus, yhteisöapu, sosiaaliturva. Suomalaisten sosiaalisen turvan historia. Helsinki: Sosiaaliturvan keskusliitto.

Rietbergen P (2015) Europe. A Cultural History. Third edition. London and New York, NY: Routledge. 
Satka M (1995) Making Social Citizenship. Conceptual Practices from the Finnish Poor Law to Professional Social Work. Jyväskylä: University of Jyväskylä.

Seppo J (1983) Uskovien yhteisö vai valtionkirkko. Uskonnolliset vähemmistöyhteisöt ja evankelis-luterilaisesta kirkosta eroaminen Suomessa vuosina 1923-1930. Helsinki: Suomen Kirkkohistoriallinen Seura.

Seppo J (1994) Church-State Relations in Finland. In: Työrinoja P (ed) The Evangelical Lutheran Church in Finnish Society. Helsinki: Church Council for Foreign Affairs.

Soikkanen H (1966) Kunnallinen itsehallinto kansanvallan perusta. Maalaiskuntien itsehallinnon historia. Helsinki: Maalaiskuntien liitto.

Statistical Yearbook of Finland (1930) Tableau 21: 'Population selon la confession de 1860 à 1928.' Helsinki.

Stenius H (1997) The Good Life is a Life of Conformity. The Impact of the Lutheran Tradition on Nordic Political Culture. In Sørensen $\varnothing$ and Stråth B (eds) The Cultural Construction of Norden. Oslo: Scandinavian University Press, pp. 161-171.

Thorkildsen D (1997) Religious Identity and Nordic Identity. In Sørensen $\varnothing$ and Stråt B (eds) The Cultural Construction of Norden. Oslo: Scandinavian University Press.

Tønnessen AV (2000) ... et trygt og godt hjem for alle? Kirkelederes kritikk av velferdsstaten etter 1945. Trondheim: Tapir Akademisk Forlag.

Tønnessen AV (2014) The Church and the Welfare State in Post-War Norway: Political Conflicts and Conceptual Ambiguities. Journal of Church and State 56(1): 13-35. 